\title{
Human rights education in patient care
}

\author{
Joanna N. Erdman
}

Correspondence:

joanna.erdman@dal.ca

MacBain Chair in Health Law and

Policy, Schulich School of Law,

Dalhousie University, Halifax, Nova

Scotia B3K6S2, Canada

\section{Biomed Central}

\begin{abstract}
This article explores how human rights education in the health professions can build knowledge, change culture, and empower advocacy. Through a study of educational initiatives in the field, the article analyzes different methods by which health professionals come to see the relevance of human rights norms for their work, to habituate these norms in everyday practice, and to espouse these norms in advocacy for social justice. The article seeks to show the transformative potential of education for human rights in patient care.
\end{abstract}

Keywords: Human rights, Education, Health professions, Patient care, Advocacy, Systemic reform

\section{Background}

Human rights education seeks to embed human rights norms into core social institutions. From the recognition that health care systems are core social institutions, human rights were introduced into health professional higher education, that is, the formal curriculum in schools of medicine, nursing and public health. Health professional education, however, presents challenges for the theory and practice of human rights education. There are administrative challenges, such as the difficulty of introducing non-clinical subjects into professional curricula, but there are also substantive challenges related to the very concept of human rights in patient care. This concept, human rights in patient care, refers to the application of legally enforceable human rights in the context of patient care, defined as the provision of services by health providers for the benefit of patients inside any health care setting, including hospitals, clinics, outreach facilities, places of detention or private homes [1]. The challenges of protecting and promoting human rights in patient care include the fact that patient care settings are often closed and intimate spaces, where providers and patients engage in a deeply personal and vulnerable way, all of which complicate the dynamics of identifying and remedying human rights violations especially in the context of structural inequalities, such as power imbalances between providers and patients, particularly those from marginalized social groups [2]. Moreover, many human rights violations in patient care stem from professional norms and institutional structures, such as defenses of certain practices on grounds of administrative efficiency, behavioral modification, or medical necessity, which present unique challenges for systemic reform as human rights law must compete with other powerful normative systems that regulate health professional conduct and contexts [2].

This article sets out to explore how education can lead health professionals to see the relevance of human rights norms for patient care, to habituate these norms in their

(c) The Author(s). 2017 Open Access This article is distributed under the terms of the Creative Commons Attribution 4.0 International License (http://creativecommons.org/licenses/by/4.0/), which permits unrestricted use, distribution, and reproduction in any medium, provided you give appropriate credit to the original author(s) and the source, provide a link to the Creative Commons license, and indicate if changes were made. The Creative Commons Public Domain Dedication waiver (http://creativecommons.org/ publicdomain/zero/1.0/) applies to the data made available in this article, unless otherwise stated. 
everyday practices of patient care, and to espouse these norms in social justice advocacy to improve the lives and health of their patients. The concept of human rights in patient care sets an ambitious frame for thinking about the transformative potential of human rights education in the health professions because it is so expansive in its scope. The concept includes the interpersonal relationship between patient and provider in the delivery of healthcare, but also reaches the systemic factors and state responsibility that shape the health care encounter itself [1].

\section{Human rights education in the health professions: post-apartheid South Africa}

Education systems usually perpetuate themselves by reference to tradition, but in times of political transition and often in a deliberate effort to break with the past, there is a greater openness to new influences. Systemic human rights abuse at the hands and with the acquiescence of health professionals characterized the regime of apartheid South Africa [3]. In 1997, the South African Truth and Reconciliation Commission found that:

the health sector through apathy, acceptance of status quo and acts of omission, allowed the creation of an environment in which the health of millions of South Africans was neglected, even at times actively compromised ... [in violation] of human rights [4].

International attention has been directed to the specific prohibition against health professionals' use of expert knowledge and skill in acts of torture and other forms of cruel, inhuman, and degrading treatment in prisons, police, and armed forces [5]. The Commission in South Africa, however, drew particular attention to the routine human rights violations of informed consent, confidentiality, and non-discrimination in the everyday practices of health professionals simply 'doing their jobs' in a deeply flawed system. Acknowledging that professional culture develops in the earliest of training, the commission identified education as a key factor that corrupted the health sector, and thus a key measure for its reform. The commission called for the integration of human rights into all health professional education.

In the 1970s, the human rights movement broadened from a strictly legal into a social enterprise with education at its core [6]. In an effort to target systemic violations, human rights education was promoted as a means to embed human rights within social institutions such as health care systems. By the 1990s, human rights education matured into a distinct field of theory and practice [7-11]. It also began to attract targeted political endorsement as reflected in the U.N. Decade of Human Rights Education (19952006) and its Programme of Action [12, 13]. At the conclusion of the decade, the Office of the High Commission for Human Rights established the World Programme for Human Rights Education to promote a common understanding of the basic principles and methodologies of human rights education, with resolutions and plans of action for its effective implementation [14]. In 2011, the U.N. General Assembly adopted the Declaration on Human Rights Education and Training in an effort to set international standards for the field [15]. Emboldened by these initiatives, governments, education 
sectors, and civil society generated training materials, teaching tools, and other resources on human rights education.

During this time, human rights education in higher education also advanced [16]. From 1968 to 2000, more than 140 universities in 59 countries established academic chairs, research centers, and programs for human rights [17]. In 2006, the Harvard School of Public Health and the University of New South Wales collected teaching materials from more than 30 health and human rights courses offered in academic faculties worldwide [18]. This collection is now housed at the University of Southern California, Institute for Global Health [19].

The integration of human rights into health professional education has had a more measured progress, despite strong international endorsement of human rights as a core component of professional competence [20, 21]. In 2005, the U.N. Special Rapporteur on the Right to Health described human rights education as "an essential starting point for equipping health professionals with the knowledge and tools to empower them to promote and protect human rights" (para 11) [22]. The Special Rapporteur further recognized the many excellent human rights training manuals, courses, and other initiatives for health professionals developed in recent years. Among the most documented is the Health and Human Rights Programme at the School of Public Health and Family Medicine in Cape Town, South Africa, developed in response to the Truth and Reconciliation Commission's call for educational reform in the country [23-29]. The field, however, continues to grow [30-34]. There is now a robust English language literature on human rights initiatives in health professional education worldwide, with a commitment to theorizing and evaluating their effectiveness. This literature grapples with questions of why and how to teach human rights in the health professions, exploring objectives and methods of practice. Felisa Tibbitts, a leading scholar of human rights education, identifies these questions as critical to the field as a whole. To move beyond a collection of interesting and discrete programs, she explains, there needs to be a theory about human rights education: its objective and methodology-where to invest energies and funding and where to create new opportunities [35].

Human rights education is not a rigorously defined term, reflecting and perhaps encouraging the many different ways in which it is conceived and practiced [36]. Nonetheless, there is broad consensus on three basic objectives of human rights education: to educate about human rights, to educate through human rights, and to educate for human rights. These objectives, albeit differently articulated, are a common analytical framework in the field [15, 37]. The first objective seeks to impart knowledge about human rights, namely, the laws and institutions designed for their protection. Building knowledge is a traditional objective of higher education. The second and third objectives of human rights education are less orthodox. To educate through human rights is to change the values, beliefs, and behaviors of an institution, that is, to enculturate human rights or to build a rights-respecting culture. To educate for human rights is to empower advocacy for social justice, to build the skills and capacity to act with and on behalf of those whose rights are denied or neglected.

Structured by these objectives, this article explores how human rights education in the health professions can build knowledge, change culture, and empower advocacy. Through an analysis of teaching materials and methods used in each objective, the goal 
of the article is to generate a theory of human rights education in the health professions and to thereby guide and encourage continued growth of the field. The analysis is based on an interpretive review of the academic English language literature on human rights curricular initiatives in health professional education (by the constraints of the literature mainly medicine, nursing, and public health) in formal diploma or university degree programs, excluding post-graduate training. Articles reviewed were limited to those that describe in sufficient detail the objectives and methods of an initiative. $[24,25,27,28,38-61]$. Initiatives were then selected for analysis that illustrated key insights and cross-cutting themes as informed by the general literatures on human rights and health professional education theory and practice.

In interpretive reviews, it is neither possible nor desirable to specify a precise review question, explicit search categories, and tightly specified inclusion criteria such that the search methods can be reproduced [62]. Human rights education is not a rigorously defined term, but rather reflects and encourages many different forms of practice. The review was designed to capture this diversity and to allow concepts and a theory of human rights education to emerge from it. The review was therefore highly inductive and iterative, crucially involving judgment and interpretation. It combined a number of strategies including searching electronic databases, but also reference chaining and using the author's legal expertise to identify and draw insights from relevant materials in adjacent fields.

These methods are appropriate to the emergent and exploratory aims of this interpretive review, which seeks to generate theory from a large and complex literature and to thereby provide a more formalized, insightful way to think about human rights education in the health professions. The review does not seek to provide a history of the field, nor a comprehensive assessment of human rights initiatives in health professional education on a global scale.

The review is also limited to health professional education rather than a broader category of health provider or worker trainings because of the unique relationship between health professions and the state $[63,64]$. First, through legal regulation of licensure and practice, including formal education, the professions are a key site of state power and therefore a key object of human rights law, which imposes obligation on the state in its exercise of power. Second, professions are characterized by their commitment to serve the collective needs of society or the public interest, a commitment integral to the privileges they enjoy from the state, but also integral to the role they can play in the protection and promotion of human rights within the state. The health professions, in other words, are unique mediators between patients and the state, the relationship at the center of human rights law.

\section{Human rights education as building knowledge}

The general practice of human rights education remains firmly rooted in law. The texts of international and regional human rights treaties, and their interpretation by courts of law and other legal institutions, continue to serve as the fundamental content of human rights education, including in the health professions. To make this legal content more accessible for diverse audiences, however, there are simplified and organized collections of health and human rights law intended for use in curricular initiatives. The Health and Human Rights Resource Guide and the Global Health and Human Rights 
Database, for example, pair health-related provisions of international treaties with key interpretations and plain language case summaries $[65,66]$.

These resources make international human rights law more accessible, but not necessarily more relevant for health professional education. They do not answer the questions: why should health professionals learn about international law? How does it affect their delivery of patient care? Relevance is a concern in human rights education, the need to firmly ground human rights in real problems that local actors, including health providers, face on a daily basis [30, 32, 67]. The most immediate relevance of law for health practice is liability, the threat of legal sanction driving behavior change. The UN Special Rapporteur on the Right to Health once noted that most health professionals whom he met had not heard of the right to health, and if they had, they worried it was something that would get them into trouble [68]. International human rights law, however, does not directly sanction health professionals except where they act as agents of the state. International law applies indirectly to patient care through state responsibility for the regulation of health professions and their practice.

In answer to this question of relevance, many human rights initiatives seek to domesticate international law by showing how its norms are reflected in and therefore enforceable through national law, including constitutional rights, statutory regulation and even 'soft law' such as patient charters and professional codes. Domestic translation, for example, is a key feature of the Open Society Foundations (OSF) initiative to build and strengthen capacity for human rights education on patient care in Eastern Europe and Central Asia [47]. In this initiative, OSF commissioned systematic reviews of national laws and regulations related to patient care, which were then cross-referenced against international human rights standards [69]. Although these reviews were intended for lawyers in the region, they proved a valuable resource and are now used for teaching in health professional programs [47].

Teaching international human rights law through local regulatory systems imparts an important lesson about the nature of human rights, namely, that despite universal legal frameworks, human rights are read into and become relevant in local contexts in remarkably different ways [70]. Human rights initiatives in health professional education may thus endeavor to contextualize the human rights content, even sometimes, presenting the dynamic between international law and local culture as something itself worthy of study. Strict education transfer or borrowing, the use of generic curricular legal content, is seldom seen in practice even when initiatives are supported by or developed with international actors [71]. In Cambodia, for example, a human rights initiative in health professional education explored the relationship between Buddhist values and human rights [53]. In national contexts with communist or socialist histories, social and economic rights tend to resonate more with the vestiges of these political traditions in national law, such as constitutional rights to health care as a state entitlement [72]. The lesson is that the norms of international human rights law can be accommodated into different legal and political traditions, and it is this resonance that often makes human rights relevant and meaningful in a local context [73]. At the same time, the contrast between international and national law can sometimes offer the more powerful insight. In Ukraine, for example, social and economic rights provide a discourse to support state entitlements to health care against a collapsing public system, while civil and political rights sustain critiques against state abuse of psychiatric institutionalization in the Soviet era [74]. 
Simple knowledge of law, however, whether international or national, has its limitations in health professional education. Legal rules can teach students what human rights require in patient care, but they rarely generate more complex understandings of why. In a UK study on the integration of law in medical education, for example, students expressed a preference for law over ethics because they saw law as offering more clear-cut answers [75]. Such an impression of law often comes from the method by which it is taught. Outsider disciplines like law may seek legitimacy in health professional education by embracing its positivist methods, for example, teaching human rights as though they were akin to the abstract, generalized knowledge of the basic sciences [76]. The provisions of international human rights treaties, however, are written in open and broad language, and mere knowledge of them rarely if ever provides clear-cut answers to the real conflicts health providers face in practice. Human rights, like all law, require interpretation.

The study of case law, for this reason, becomes important in human rights education. The jurisprudence of the European Court of Human Rights, for example, offers a rich source of educational content. Its case law covers a range of patient care issues such as mistreatment in reproductive and mental health, access to medicines, information disclosure, informed consent, and physician-assisted death [77-80]. Learning law through the study of its application, what is known as the case method in legal education, offers a number of advantages. Not only does it contextualize the rules of law within a set of facts but it also requires students to engage with legal reasoning, that is, the analytic work of moving between fact and law [81]. Students are asked to follow the logic of legal argument, to identify and perhaps contest the facts and assumptions that guide it, and to assess the ultimate judgment reached. These are critical analytical skills that students then carry with them, a new capacity to evaluate the human rights implications of an institutional policy or a clinical practice. Moreover, by reasoning together but arriving at different conclusions about the correctness of a legal judgment, students reveal the possibility of multiple rather than singular answers in law. This again communicates something about the nature of law, namely, that the content of international human rights law is dynamic, evolving over time through ongoing and collective interpretation. To understand the nature of law in this way opens up a new relationship between the health professions and law. Rather than being merely subject to law, they have a role to play in the making of law. After all, it is ultimately health providers who will give true meaning to the abstract standards of human rights law through their interpretation in the daily practice of patient care.

The case method yet has its shortcomings. Most importantly for health professional education, legal cases present a fixed and often simplistic account of the circumstances that gave rise to human rights allegation or violations and provide only one account of their resolution [82]. Legal cases can rarely capture the complexity of unfolding conflicts, competing interests, and institutional constraints that underlie human rights violations. Against the retrospective study of legal cases, problem solving through human rights case studies is thus a valued method in health professional education. Constructed from a diverse set of materials-including law, professional guidance, clinical notes, social science studies, and first person testimonies-case studies are designed to reflect a range of perspectives on a human rights controversy and to generate multiple pathways to its resolution. In the Cambodian initiative, for example, a case study 
focused on the role of health professionals in torture included excerpts from a Khmer Rouge interrogator's manual in an effort to expose the mindset of those who torture and the political ideology behind state torture [53]. The objective of case studies is to present international human rights law not only as a standard against which to assess action but also as a framework within which to understand, to work through, and ultimately to resolve the conflicts that breed violations.

Case studies in dual loyalty, where health professionals act for persons and purposes other than the wellbeing of their patients, present immediate and relevant conflicts for engaging in this work [1]. A curriculum module in a new medical school in northern Israel, for example, asked students to reflect on contemporary ethical issues against the abuses of medicine during the Third Reich, an effort to better see and understand the professional power of medicine and the capacity for its abuse [58]. Apart from the egregious cases of medical abuse for repressive state ends, dual loyalty conflicts can underlie more routine human violations in patient care. The global economic deregulation of health care, for example, where commercial forces drive delivery practices and private profits measure quality of care can breed systemic conflicts of interest in patient care [83]. Dual loyalty conflicts, however, do not always represent violations of human rights in themselves. Rather international human rights law, in many cases, justifies restrictions on patient rights for any number of state interests, including public health and criminal justice. This is why dual loyalty conflicts present good case studies. They reveal human rights violations as not the arbitrary actions of wayward individuals, but rather, as the predictable outcomes of the conflicting interests and incentives in health care systems [84].

The Special Rapporteur on the Right to Health has explicitly acknowledged these complex pressures that underlie human rights violation in patient care, and that often leave health providers believing or feeling they have no choice but to violate human rights [22]. Providers are constrained in their ability to provide quality care where they cannot work under decent conditions with professional independence [1]. The failure to acknowledge these institutional and structural barriers frustrates the effectiveness of human rights education [25, 85]. Holding healthcare providers responsible for circumstances they cannot change, moreover, may engender backlash against human rights as unfairly punitive [86]. Under international law, governments are required not only to respect human rights in patient care but also to fulfill the conditions necessary for their realization [87]. This is where international law becomes directly relevant to health professionals because, as explicitly stated by the Special Rapporteur, the right to health imposes obligations of fulfillment on the state to "build[] an environment that supports the adoption of rights-based approaches by the health professional community" (para 16) [22]. Safe working conditions and adequate health resources are human rights entitlements that health professionals can rightly claim from the state. This is the most critical knowledge gained from a human rights analysis in patient care: changing health care practice requires changing the health care institution that sustains it.

\section{Human rights education as changing culture}

A second objective of human rights education is to enculturate human rights within an institutional context, that is, to have health professions embrace human rights values as their own - a remoralization of the health care system. Human rights education, in 
other words, seeks to change health care practice by changing what people value, what they feel, what they believe, and it seeks to do so by shifting the frame of reference through which people see themselves and their world, leading them to ask new questions about their own actions and the actions of others. This is the reflexive learning of human rights education, where the knowledge and understanding gained is of oneself and one's context. This objective of human rights education explicitly recognizes that especially in the professions, formal education is a core part of the socialization process that creates normative ways of thinking and acting-the social norms of patient care.

As a cultural project, human rights education focuses on exposing the stereotypes, prejudices, and other harmful social and cultural norms used to rationalize mistreatment of marginalized or vulnerable groups in patient care [1]. As observed by the U.N. Special Rapporteur on Torture, health care practices violent or abusive in their very nature are routinely rationalized on grounds of administrative efficiency, behavior modification, or medical need, which breeds a culture of impunity in health care settings $[2,88]$. People who use illicit drugs are denied pain treatment on the basis that it fuels addiction. The competent decisions of people with psycho-social disabilities are disregarded in their supposed best interests. Women living with HIV are sterilized against their will on the belief that they should not bear or parent children. Identified sex workers are subject to mandatory HIV testing and confidentiality breaches for public health protection. These rationalizations reflect a complex amalgam of routinized practice, personal belief, and social norms.

To effect cultural change, human rights education thus seeks to engage with the dominant institutional culture that not only sustains these practices but also leads health providers to think them unproblematic. One aspect of institutional health professional culture that human rights education can tackle is that of strict scientific objectivity, which may bring with it an emotional detachment from everyday life, cutting providers off from valuable sources of information, insight, and understanding about their patients and the conditions of their lives [89]. Human rights education, as a cultural project, is partly an effort to keep health care 'human.' The intention is not to devalue biomedical paradigms in health professional education but to recognize and remedy their harmful effects in patient care [76]. A global initiative to integrate reproductive rights into medical education, for example, recommends integrating human rights training with the learning of clinical skills, such as the right to respect for dignity with the learning of breast and pelvic examination techniques that minimize pain and discomfort [50]. A role-play exercise in a third year medical school course in Ankara, Turkey asked students to take on the perspective of patients, to engage with how patients think and feel in a clinical setting [40].

The philosophy and methods of experiential education - that is, the infusion of direct experience into the learning environment-is also a way to encourage patient-provider engagement rather than detachment [90]. Bringing the lived experience of marginalized communities into human rights education, through guest engagements and site visits, can disrupt false but persistent beliefs and norms latent in scientific objective claims of medical or public health need [91]. Where people speak on their own behalf, and give firsthand account of their lives, the stereotypes and prejudices that underlie human rights violations are more difficult to sustain $[1,92]$. Health professional education that does not teach 'about' people but 'with' people reflects the principle of participation, 
which is core to health and human rights doctrine [93]. In an initiative led by Ipas to promote reproductive rights training in medical and nursing schools in Central America, for example, new physicians credited having more respectful and empathetic attitudes toward their patients to a better understanding of the social determinants underlying the health needs of their patients [59]. A public health course focused on underserved communities on the USA-Mexico border similarly emphasized the connection between students' growing respect for patients and their learning about the community assets, cultural richness, and historic resilience that families and individuals bring to health encounters [60]. Supplementing direct experience with a more formalized study of social history, drawing on disciplines such as anthropology, sociology, and political history, allows health professionals to further contextualize the conditions of peoples' lives within larger historical frames of reference [57]. By acknowledging members of marginalized groups as credible and trusted sources of information, by valuing their insights, opinions, and experiences, human rights education not only challenges authoritarian forms of knowledge in professional education but can also fundamentally shift the power dynamic between provider and patient in health care settings. Such experiential human rights education, above all, seeks to foster empathy in an effort to change that moment when a doctor or nurse faces a patient in the examination room and struggles to listen, to understand, and to respect them [94].

International human rights law recognizes the need for cultural change within the health professions to secure equality rights in health care, especially for marginalized and vulnerable groups, and specifically names education as a measure to achieve it. The U.N. Convention on the Rights of Persons with Disabilities calls for education measures to ensure "that health professions provide care of the same quality to persons with disabilities ... including on the basis of free and informed consent" [95]. The U.N. Convention on the Elimination of all forms of Discrimination against Women similarly requires "that the training curricula of health workers include comprehensive, mandatory, gender-sensitive courses on women's health and human rights, in particular gender-based violence" [96].

\section{Human rights education as empowering advocacy}

Human rights education as cultural change recognizes the therapeutic value in bearing witness to peoples' lives, but there is also a social justice agenda in this act [97]. By bearing witness and publicly testifying to human rights violations, health professionals become advocates for human rights. In its last and most radical objective, human rights education seeks to build the capacity and skills of health professionals to use their knowledge of how social structures impact on health, knowledge gained through patient care, to advocate for social change $[28,49,51]$.

Under this objective, human rights education follows the 19th century tradition of social medicine, famously captured in Virchow's characterization of the physician as the natural advocate for the poor [98]. Through the care provided to patients in community clinics, emergency wards, and operating theaters, health professionals bear direct witness to how social discrimination, abject deprivation, and structural violence shape the health and lives of their patients. In the IPAS initiative on reproductive health and rights education in Central America, graduate physicians expressed their frustration in 
contraceptive counseling where they were powerless to address gendered social and economic barriers that limited women's free exercise of the right to decide the number and spacing of their children [59]. Human rights initiatives therefore incorporate human rights advocacy skills within health professional training, especially clinical training, to provide health professionals with the tools to act on a larger scale. Of particular note is human rights education in asylum clinics across the USA, many partnered with the advocacy organization Physicians for Human Rights, to provide medical evaluations and affidavits for asylum seekers [41, 42, 56, 99]. In these initiatives, students train and participate in the medico-legal process of asylum seeking, learning how to document health status and needs for the purposes of legal affidavits. The goals of this work are to improve the quality of life for victims of torture and persecution by supporting their efforts to obtain legal asylum, but also, by connecting them with needed health care and other social services. Through clinical practice, moreover, the students and physicians with whom they work learn about and in turn can raise social awareness about the health care and other needs of a deeply vulnerable social group. The asylum clinic example shows that human rights advocacy need not always take a confrontational stance against the state. Health professionals may be equally powerful advocates by collaborating with the state to develop or implement human rights-based programs and policies, such as asylum. What is sometimes referred to as a duty or responsibility of health professionals to act individually and collectively for human rights not only stems from their specialized knowledge but also from their social standing which makes their public statements more likely to be heard and more difficult to ignore $[39,61]$. The U.N. Special Rapporteur on the Right to Health has thus endorsed various forms of "practical instruction in how to implement a human rights approach" including "how to identify violations, empower patients or colleagues to defend their human rights, and promote [state] accountability" (para 15) [22].

This is human rights education at its most radical, but also its most contested. Human rights education as empowering advocacy challenges a tradition of professional education as not the engine of social reform, but a potent force in preserving the status quo [45]. Human rights initiatives in health professional education therefore sometimes require and are supported by international donors and developed in partnership with civil society [17, 67]. Even today, human rights education in many contexts retains an outsider status in the health professions, cast as political, confrontational, even unnecessary or inappropriate to professional education as well as professional practice and identity $[28,100]$. A study on the teaching of human rights in nursing courses in the UK, for example, noted that prejudice against human rights educators who were also engaged in human rights campaigning or organizing was based on the questionable assumption that their activism undermined the objectivity required in teaching, leading to charges of political bias or even indoctrination [32].

Human rights educators use different strategies to counter professional opposition to their work. Role modeling, for example, can be used to show that human rights advocacy is not a derivation from, but part of a long and celebrated tradition in health professionalism: Black nurses in South Africa who went on strike in 1949 to protest inequalities at the Sulenkama Mission Hospital [55], psychiatrists in Ukraine who spoke out against state psychiatric practices only to be hospitalized themselves as dissidents [74]; the UK Royal College of General Practitioners which issued a policy statement on 
the right of failed asylum seekers to primary health care [48]. These are all historical examples that can provide role models for students and ideals from which to build a professional identity [101].

Human rights initiatives in health professional education may also seek to support if not embolden faculty members to develop and teach human rights in formal university curriculum recognizing their outsider status. Fostering a community of practice is a tool used for this task in human rights education generally, including in health professional education [100]. The human rights program at the University of Cape Town, for example, provides training and in-kind support for health professional educators to develop human rights courses across South Africa and in other African countries [46]. The training includes a specific theme on institutional reform, where alumni share experiences and strategies of seeking institutional support, even protection, for human rights education. OSF supported the development of a similar online community of practice for Eastern Europe and Central Asia, now housed with the Association of Schools of Public Health of the European Region [47, 102].

These communities offer not only an opportunity to develop and share best practices but also a safe and supportive space to build professional alliances and an alternative institutional culture. Yet the need for these alternative communities raises questions about the institutionalization of human rights education in institutions of higher education: does the professionalization of human rights education inevitably lead to its deradicalization? If human rights education is a tool for social justice-to limit state power, to protect against state power, to seize state power-why would institutions of the state foster it, and more importantly, what happens when they do? In many national contexts, government ministries retain tight control over health professional curriculum through the funding, accreditation, and licensing of both public and private institutions. Even more concerning, some state universities discourage faculty and students from expressing their views publicly or participating in public debate, prohibiting political activities [38]. These restrictions make academic freedom, and associated human rights of freedom of expression and association, critical to achieving the radical objectives of human rights education.

Nonetheless, reforms in systems worldwide have opened higher education to new influences. Regulatory measures, like the Bologna Guidelines to secure European standards in higher education, have brought opportunity for curricular reform in the region. An elective course on Discrimination, Health and Globalization, for example, was introduced at the Faculty of Medicine, University of Geneva, when the faculty adopted these guidelines [44]. Moreover, changing demographics in universities where students begin to more fully reflect a spectrum of social experience can open health professional education to new influences and orientations [60]. Ultimately, one cannot deny nor predict the ways the "university may become ... the locus of intellectual resistance and critique, the breeding ground for a human rights and political opposition" [103].

\section{Conclusions}

Human rights education in the health professions carries an ambitious set of objectives: to teach about human rights, to teach through human rights, and to teach for human rights. It entails acquiring knowledge and skills, socializing around values, and 
producing meaningful change. Human rights education is envisioned as a site of knowledge, change, and justice. This is why human right education is 'transformative' in its vision and practice [8]. There is something radical at its roots-human rights education is an effort to realize human rights not in singular, heroic moments, but in systemic reform of the most basic and fundamental institutions of society. These institutions include the health care system, and the guardians of that system, the health professions, and there is no better place to begin their transformation than in the world of patient care.

\section{Acknowledgements}

I would like to acknowledge Tamar Ezer and Judith Overall for their comments and feedback on the baseline report, which served as a foundation for this article.

\section{Funding}

I received financial support from the Open Society Foundations for a baseline report on human rights education in the health professions, which served as a foundation for this article.

Availability of data and materials

Not applicable. Data sharing is not applicable to this article as no datasets were generated or analyzed during the current study.

\section{Author's contributions}

JNE developed the concept of the paper, researched and drafted all sections of it.

Ethics approval and consent to participate

Not applicable. This study does not report on or involve the use of any animal or human data or tissue.

\section{Consent for publications}

Not applicable. This paper does not contain any individual person's data in any form.

\section{Competing interests}

I contributed to the Open Society Foundations' Initiative on Higher Education in Law, Human Rights and Patient Care, overseeing the development of a case studies series, completed by the Health Equity and Law Clinic at the University of Toronto, and participating as a guest faculty member at teaching workshops in Macedonia and Kyrgyzstan.

\section{Publisher's Note}

Springer Nature remains neutral with regard to jurisdictional claims in published maps and institutional affiliations.

Received: 2 December 2016 Accepted: 30 June 2017

Published online: 11 July 2017

\section{References}

1. Cohen J, Ezer T. Human rights in patient care: a theoretical and practical framework. Health Human Rights. 2013; 15(2):7-19.

2. UN General Assembly. Report of the Special Rapporteur on torture and other cruel, inhuman or degrading treatment or punishment, Juan E. Méndez. 2013. 1 February. A/HRC/22/53.

3. Baldwin-Ragaven L, London L, De Gruchy J. An ambulance of the wrong colour: health professionals, human rights and ethics in South Africa. Cape Town: University of Cape Town Press; 1999.

4. Truth and Reconciliation Commission. Truth and Reconciliation Commission of South Africa Report. Cape Town. 1998;4(5):250.

5. UN General Assembly. Principles of medical ethics relevant to the role of health personnel, particularly physicians, in the protection of prisoners and detainees against torture and other cruel, inhuman or degrading treatment or punishment. 1982. 18 December. A/RES/37/194.

6. Ramírez FO, Suárez D, Meyer JW. The worldwide rise of human rights education. In: Benavot A, Braskavsky C, editors. School knowledge in comparative and historical perspective: changing curricula in primary and secondary education. Hong Kong: Comparative Education Research Centre; 2006. p. 35-52.

7. Bajaj M. Human rights education: ideology, location and approaches. Hum Rights Quart. 2011;33(2):481-508.

8. Bajaj M, Cislaghi B, Mackie G. Advancing transformative human rights education: Appendix D to the report of the Global Citizenship Commission. Cambridge, UK: Open Book Publishers; 2016.

9. Lenhart V, Savolainen K. Human rights education as a field of practice and of theoretical reflection. Int Rev Educ. 2002;48(3-4):145-58.

10. Lohrenscheit C. International approaches in human rights education. Int Rev Educ. 2002;48(3-4):173-85.

11. Tibbitts F, Fernekes WR. Human Rights Education. In: Totten S, Pedersen JE, editors. Teaching and studying social issues: major programs and approaches. Charlotte, NC: Information Age Publishing; 2011. p. 87-118.

12. UN General Assembly. Resolution 48/127, Human rights education decade, adopted 20 December. 1993. A/RES/48/127. 
13. UN General Assembly. Resolution 49/184, United Nations Decade for Human Rights Education, adopted 23 December. 1994. A/RES/49/184.

14. UN General Assembly. Resolution 59/113 A, World Programme for Human Rights Education, adopted 10 December. 2004. A/RES/59/113.

15. UN General Assembly. Resolution 66/137, United Nations Declaration on Human Rights Education and Training, 19 December 2011. 2011. A/RES/66/137.

16. UN High Commission for Human Rights. World Programme for Human Rights Education, Plan of Action, 2nd Phase. 2010. A/HRC/15/28.

17. Suárez D, Bromley S. Professionalizing a global social movement: universities and human rights. Am J Educ. 2012;118(3):253-80.

18. Tarantola D, Gruskin S. Health and human rights education in academic settings. Health Hum Rights. 2006;9:297-300.

19. Health and Human Rights Syllabi Database. https://globalhealth.usc.edu/ghhr/resources-databases/hhrsyllabi/. Accessed 5 July 2017.

20. World Medical Association. Resolution on the Inclusion of Medical Ethics and Human Rights in the Curriculum of Medical Schools Worldwide. Adopted 51st Annual General Assembly, 1999, revised $66^{\text {th }}$ Annual General Assembly, 2015. https://www.wma.net/policies-post/wma-resolution-on-the-inclusion-of-medical-ethics-and-human-rights-inthe-curriculum-of-medical-schools-world-wide/. Accessed 5 July 2017.

21. International Council of Nurses. Position statement: nurses and human rights, International Council of Nurses. Adopted 1998, revised 2006 and 2011. http://www.icn.ch/images/stories/documents/publications/position statements/E10_Nurses_Human_Rights.pdf. Accessed 5 July 2017.

22. UN General Assembly. Report of the Special Rapporteur on the right of everyone to the enjoyment of the highest attainable standard of physical and mental health, Paul Hunt. 2005. 12 September. A/60/348.

23. University of Cape Town, School of Public Health and Family Medicine. Health and Human Rights Programme. http://www.publichealth.uct.ac.za/phfm_key-programmes-phm. Accessed 5 July 2017.

24. Baldwin-Ragaven L. Prioritising human rights training for health professionals. S Afr Med J. 1998;88:1377.

25. Baldwin-Ragaven L, London L, De Gruchy J. Learning from our apartheid past: Human rights challenges for health professionals in contemporary South Africa. Ethn Health. 2000;5:227-41.

26. Hoffman M, Coetzee D, Hodes R, London L. From comprehensive medicine to public health at the University of Cape Town: a 40-year journey. S Afr Med J. 2012;102(6):442-5.

27. London L, Baldwin-Ragaven L. Human rights and health: challenges for training nurses in South Africa. Curationis. 2008;31(1):5-18.

28. London L, Baldwin-Ragaven L, Kalebi A, Maart S, Petersen L, Kasolo J. Developing human rights competencies for South African health professional graduates. S Afr Med J. 2007:97(12):1269-70.

29. Mayers P. Introducing human rights and health into a nursing curriculum. Curationis. 2007:30(4):53-60.

30. Sonis J, Gerenflo D, Jha P. Teaching of human rights in US medical schools. JAMA. 1996;276:1676-78.

31. Brenner J. Human rights education in public health graduate schools: 1996 survey. Health Human Rights. 1996:2(1):129-39.

32. Chamberlain M. Human rights education for nursing students. Nurs Ethics. 2001;8(3):211-22.

33. lacopino V. Teaching human rights in graduate health education. In: Marks SP, editor. Health and human rights: the educational challenge. Boston: François-Xavier Bagnoud Center for Health and Human Rights; 2002. p. 21-42.

34. Cotter LE, Chevrier J, El-Nachef WR, Radhakrishna R, Rahangdale L, Weiser SD, et al. Health and Human Rights Education in U.S. Schools of Medicine and Public Health: Current Status and Future Challenges. PLoS One. 2009;4(3):e4916.

35. Tibbitts F. Understanding what we do: emerging models for human rights education. Int Rev Educ. 2002;48(3-4):159-71.

36. Flowers N. How to define human rights education?-a complex answer to a simple question. In: Georgi VB, Seberich $M$, editors. International perspectives in human rights education. Gütersloh: Bertelsmann Foundation Publishers; 2004. p. 105-27.

37 Struthers AEC. Human rights education: educating about, through and for human rights. Int J Hum Rights. 2015;19(1):53-73.

38 Allotey PA, Diniz S, Dejong J, Delvaux T, Gruskin S, Fonn S. Sexual and reproductive health and rights in public health education. Repro Health Matters. 2011;19(38):56-8.

39 Andreopoulos G. Human rights education and training for professionals. Int Rev Educ. 2002;48(3-4):239-42.

40 Arda B. Human Rights in Medical Ethics Education. Med Sci Indicator. 2004;14(1):5-7.

41 Asgary R, Saenger P, Jophlin L, Burnett DC. Domestic global health: a curriculum teaching medical students to evaluate refugee asylum seekers and torture survivors. Teach Learn Med. 2013:25(4):348-57.

42 Asgary R. Graduate public health training in healthcare of refugee asylum seekers and clinical human rights: evaluation of an innovative curriculum. Int J Public Health. 2016;61(3):279-87.

43 Chastonay P, Klohn AM, Zesiger V, Freigburghaus F, Mpinga EK. Developing a health and human rights training program for French speaking Africa: lessons learned, from needs assessment to a pilot program. BMC Intl Health Hum Rights. 2009;9:19.

44 Chastonay P, Zesiger V, Ferreira J, Mpinga EK. Training medical students in human rights: a fifteen-year experience in Geneva. Can Med Educ J. 2012;3(2):e151-8.

45 Dharamsi S, Ho A, Spadafora SM, Woollard R. The physician as health advocate: translating the quest for social responsibility into medical education and practice. Acad Med. 2011;86:1108-13.

46 Ewert EG, Baldwin-Ragaven L, London L. Training trainers in health and human rights: implementing curriculum change in South African health sciences institutions. BMC Med Educ. 2011;11:47. doi:10.1186/1472-6920-11-47.

47 Ezer T, Overall J. Advancing human rights in patient care through higher education in Eastern Europe and Central Asia. Health Hum Rights. 2013;15(2):54-68.

48 Fitchett JR, Ferran E, Footer K, Ahmed N. Health and human rights: an area of neglect in the core curriculum? J Med Ethics. 2011;37(4):258-60

49 Hannibal K, Eisenberg C, Heggenhougen K. Integrating human rights into medical education. Am Med Assoc J Ethics. 2004:6:12-3. 
50 Haslegrave M. Integrating sexual and reproductive rights into the medical curriculum. Best Pract Res Clin Obstet Gynaecol. 2006;20(3):433-45.

51 Hixon AL, Yamada S, Farmer PE, Maskarinec GG. Social justice: the heart of medical education. Soc Med. 2013;7(3):161-8.

52 Hulsizer MR, Wolf LM. Enhancing the role of international human rights in psychology curriculum. Psychol Teach Learn. 2012;11(3):382-7.

53 Keller AS, Horn SK, Sopheap S, Otterman G. Human rights education for Cambodian health professionals. Health Hum Rights. 1995;1(3):256-71.

54 London L. Training trainers in health and human rights. S Afr J Bioethics Law. 2011;4(2):106.

55 Mokoena JD. Construction of a model for human rights education in the health professions (Thesis PhD Health Sciences). South Africa: University of Limpopo; 2002.

56 Prascan N, Stuken N, Mishori R. A student-run asylum clinic to promote human rights education and the assessment and care of asylum seekers. Journal of Student Run Clinics. J Student Run Clinic. 2016, http:// journalsrc.org/index.php/jsrc/article/view/18/18. Accessed 5 July 2017.

57 Premkumar A, Raad K, Haidar MH. Rethinking the social history in the era of biolegitimacy: global health and medical education in the care of Palestinian and Syrian refugees in Beirut, Lebanon. Anthro Med. 2016;23(1):14-29.

58 Reis SP, Wald SP. Contemplating medicine during the Third Reich: scaffolding professional identity formation for medical students. Acad Med. 2015;90(6):770-73.

59 Reyes HLM, Padilla Zuniga K, Billings DL, Blandon MM. Incorporating human rights into reproductive health care provider education programs in Nicaragua and El Salvador. Rev Panam Salud Publica. 2013;34(1):54-9.

60 Rosales CB, Coe K, Ortiz S, Gámez G, Stroupe N. Social justice, health, and human rights education: challenges and opportunities in schools of public health. Public Health Rep. 2012;127(1):126-30.

61 Zion D. Extending the clinical contract: advocacy as a part of ethical health care for asylum seekers. Am J Bioethics. 2013;13(7):19-21.

62 Dixon-Woods M, Gavers D, Agarwal S, Annandale E, Arthur A, et al. Conducting a critical interpretive synthesis of the literature on access to healthcare by vulnerable groups. BMC Med Res Methodol. 2006;6(35). doi:10. 1186/1471-2288-6-35.

63 Johnson T, Lark G, Saks M, editors. Health Professions and the State in Europe. London: Routledge; 1995.

64 Kuhlmann E. Modernizing health care: reinventing professions, the state and the public. Bristol, UK: The Policy Press; 2006.

65 François-Xavier Bagnoud Center for Health and Human Rights. Health and Human Rights Resource Guide. https:// www.hhrguide.org/. Accessed 5 July 2017.

66 Lawyers Collective, O’Neill Institute for National and Global Health Law. Global Health and Human Rights Database. http://www.globalhealthrights.org/. Accessed 5 July 2017.

67 Mihr A, Schmitz HP. Human rights education (HRE) and transnational activism. Hum Rights Q. 2007;29(4):973-93.

68 UN General Assembly. Report of the Special Rapporteur on the right of everyone to the enjoyment of the highest attainable standard of physical and mental health, Paul Hunt. 17 January. 2007. A/HRC/4/28, para. 43.

69 Beletsky L, Ezer T, Overall J, Byrne I, Cohen J. Advancing human rights in patient care: practitioner guides. New York: Open Society Foundations; 2013.

70 Shelton D, editor. International law and domestic legal systems: incorporation, transformation, and persuasion. Oxford: Oxford University Press; 2011.

71 Beech J. Who is Strolling through the Global Garden? International Agencies and Educational Transfer. In. Cowen E, Kazamias AM, editors. International Handbook of Comparative Education. Dordecht: Springer; 2009. p. 341-57.

72 Tarrow N. Human rights education: alternative conceptions. In: Lynch J, Modgil C, Modgil S, editors. Human rights, education and global responsibilities: cultural diversity and the schools. London: Falmer Press; 1992. p. 21-50.

73 Zignon J. Rights, responsibility and health services: human rights as an idiomatic language of power. In Mold A, Reubi D. Assembling Health Rights in Global Context: Genealogies and Anthropologies. London and New York: Routledge; 2013.

74 Yanokovsky S. Neoliberal transitions in Ukraine: the view from psychiatry. Anthropol East Eur Europe Rev. 2011;29(1):35-49.

75 Preston-Shoot M. McKimm J, Teaching, learning and assessment of law in medical education. UK: The Higher Education Academy; 2010.

76 Hafferty FW, Franks R. The hidden curriculum, ethics teaching and the structure of medical education. Acad Med. 1994;69:861-71.

77 European Court of Human Rights. Factsheet-Health. May 2016. http://www.echr.coe.int/Documents/FS_Health_ ENG.pdf . Accessed 5 July 2017.

78 European Court of Human Rights. Factsheet-Reproductive Rights. December 2015. http://www.echr.coe.int/ Documents/FS_Reproductive_ENG.pdf. Accessed 5 July 2017.

79 European Court of Human Rights. Factsheet-Detention and Mental Health. April 2016. http://www.echr.coe.int/ Documents/FS_Detention_mental_health_ENG.pdf . Accessed 5 July 2017.

80 European Court of Human Rights. Factsheet-End of Life and the European Convention on Human Rights. July 2015. http://www.echr.coe.int/Documents/FS_Euthanasia_ENG.pdf. Accessed 5 July 2017.

81 Sliwinki S. Thinking without banisters: towards a compassionate inquiry into human rights education. Educ Theory. 2004:55(2):219-30.

82 Coysh J. The dominant discourse of human rights education: a critique. J Hum Rights Pract. 2014;6(1):89-114.

83 Brezis M, Wiist W. Vulnerability of health to market forces. Med Care. 2011:49(3):232-47.

84 Bloche G. Clinical loyalties and the social purposes of medicine. JAMA. 1999;281(3):268-74.

85 Vivian LM, Naidu CS, Keikelame MJ, Irlam J. Medical students' experiences of professional lapses and patient rights abuses in a South African health sciences faculty. Acad Med. 2011;86:1282-87.

86 London L. What is a human rights based approach to health and does it matter? Health Hum Rights. 2008;10(1):65-80.

87 UN Committee on Social, Economic and Cultural Rights. General Comment No. 12: Article 12 of the Convention (The Right to the Highest Attainable Standard of Health). 2000. E/C.12/2000/4), para 33. 
88 Centre for Human Rights and Humanitarian Law, Washington College of Law. Torture in health Care Settings: Reflections on the Special Rapporteur on Torture's 2013 Thematic Report. 2014. http://antitorture.org/wp-content/ uploads/2014/03/PDF_Torture_in_Healthcare_Publication.pdf. Accessed 5 July 2017.

89 Cribb A, Bignold S. Towards the reflexive medical school: the hidden curriculum and medical education research. Stud High Educ. 1999;24(2):195-209.

90 Itin CM. Reasserting the philosophy of experiential education as a vehicle for change in the 21st century. J Experiential Ed. 1999;22(2):91-8.

91 Oandasan IF, Barker KK. Educating for advocacy: exploring the source and substance of community-responsive physicians. Acad Med. 2003;78(1):s16-9.

92 Baxi U. Random Reflections on the (Im)possibility of Human Rights Education. Paper given at International Consultation on the Pedagogical Foundations of Human Rights Education, La Catalina, Costa Rica, 22-26 July, 1996. http://www.pdhre.org/dialogue/reflections.html. Accessed 21 Apr 2017.

93 Tibbitts F. Transformative learning and human rights education: taking a closer look. Intercult Educ. 2005;16(2):107-13.

94 Leaning J. Human rights and medical education. BMJ. 1997;375:1390.

95 UN General Assembly. Convention on the Rights of Persons with Disabilities. 2006. A/RES/61/06, Art. 25(d).

96 UN Committee on the Elimination of Discrimination against Women. General Recommendation No. 24: Article 12 of the Convention (Women and Health). 1999. A/54/38/Rev.1. Para 31(f).

97 Meintjes G. Human rights education as empowerment: reflections on pedagogy. In: Andreopoulos GJ, Claude RP, editors. Human rights education for the twenty first century. Philadelphia: University of Pennsylvania Press; 1997. p. 64-9.

98 Brown TM, Fee E. Rudolf Carl Virchow: medical scientist, social reformer, role model. Am J Public Health. 2006;96(12):2104-05.

99 Physicians for Human Rights, The Asylum Program, http://physiciansforhumanrights.org/asylum/student-asylumclinics.html. Accessed 5 July 2017.

100 Suárez D. Education professionals and the construction of human rights education. Comp Educ R. 2007;51:48-70.

101 Kristjanson K. Emulation and the use of role models in moral education. J Moral Educ. 2006;35(1):37-49.

102 Health Rights. Community of Practice, http://cop.health-rights.org/. Accessed 5 July 2017.

103 Steiner H. The university's critical role in the human rights movement. Harvard Hum Rights J. 2002;15:317-28.

\section{Submit your next manuscript to BioMed Central and we will help you at every step:}

- We accept pre-submission inquiries

- Our selector tool helps you to find the most relevant journal

- We provide round the clock customer support

- Convenient online submission

- Thorough peer review

- Inclusion in PubMed and all major indexing services

- Maximum visibility for your research

Submit your manuscript at www.biomedcentral.com/submit 